\title{
УСТНЫЕ РАССКАЗЫ О ТЮВЭ: КЛАССИФИКАЦИЯ СЮЖЕТОВ ПО ЗАПИСЯМ НАЧАЛА XXI BEКА
}

\section{Людмила Лобанова \& Алексей Рассыхаев sergejluda@mail.ru \& rassyhaev@mail.ru}

\begin{abstract}
Аннотация: В работе представлена подборка полевых материалов о местном колдуне Тювэ, бытующих в локальной фольклорной традиции вишерских коми. Тексты записаны в последние годы в Корткеросском районе Республики Коми. Материалы предваряются вступительной статьёй и указателем сюжетов и мотивов. Аутентичные тексты даны с переводом на русский язык.
\end{abstract}

В публикации представлены устные рассказы о Тювӧ, записанные авторами в 2010-2015 гг. во время фольклорных әкспедиций Института языка, литературы и истории Коми НЦ УрО РАН в бассейне реки Вишера (коми Висер) в населённых пунктах Корткеросского района Республики Коми: с. Большелуг (Ыджыдвидз), дер. Выльыб, Зулоб (Зулӧб), Ивановская (Джиян); с. Богородск (Висер), деревни Сюзяыб, Троищк (Типӧсикт); с. Нившера (Одыб), деревни Ивановка (Елель), Русановская (Рочсикт), Лымва, Боровск (Ягвыв), Тист, Алеквсеевка (Озын).

Полевые материалы начала XXI века отражают современное состояние несказочной прозы коми о колдуне Тювэ, образ которого изучался практически всеми коми фольклористами, начиная 
с Каллистрата Жакова. Начав свой путь в науке с изучения фольклора коми, будущий писатель и философ К. Ф. Жаков в 1900 г. побывал на Вишере и записал сказки и «суеверные рассказы из охотничьего быта», в т. ч. о «лесном колдуне» Тювӧ от Тараса Ивановича Игушева. В переводе на русский язык тексты были опубликованы в статье К. Ф. Жакова «Зырянские сказки» (1908). Впоследствии предания о Тювэ публиковались в сборниках по несказочной прозе коми (Рочев 1984, Анкудинова 2005, Лимеров 2005), отдельные исследования посвящены изучению фольклорного образ Тювэ (Рочев 1994, Конаков 1999), а также выявлению реального прототипа фольклорного героя (Панюков 2002).

Для публикации отобраны наиболее репрезентативные тексты, сопровождающиеся указателем мотивов и сюжетов.

\section{Указатель сюжетов и мотивов устных текстов о Тювэ}

\section{І. СОЦИАЛЬНЫЙ СТАТУС ТЮВЭ:}

I.А.1. Ранее живший человек (коркӧ вӧвлӧма, збыль морт): $1,2,3,4,5,6,7,8,9,11,12,15,16,17,18,19,20,21,22,24$, $25,26,29$

\section{I.A.2. Известная личность: 16}

І.Б. Пришлый человек: 8, 19

І.Б.1. Пришёл с низовьев вместе с женой: 7

І.Б.2. Политссыльный: 19

I.B.1. Богатый человек, купец: 8

I.B.2. Охотник: 26

I.В.3. У Тювэ было хозяйство, скот: 8, 16

I.B.4. Тювэ жил с женой: 8, 18

\section{II. МЕСТО ЖИТЕЛЬСТВА ТЮВЭ:}

II.A.1. Тювә кӧдж: 1

II.A.2. Тювэ: 5

II.A.3. Тювэ керес: 7, 8, 16 
II.A.4. Тювэ пос: 9

II.Б. На р. Пукдым: 8, 16, 17, 18, 22

II.В.1. Село Нившера: 21

II.В.2. Деревня Тист: 29

II.Г.1. В верховьях р. Вишера: 9

II.Г.2. В низовьях реки: 12

\section{III. ОСОБЕННОСТИ ТЮВЭ:}

\section{III.А. Обладает знанием}

III.A.1.1. Знающий-тӧдысь: 2, 6, 7, 8, 11, 12, 17, 18, 22, 24

III.A.1.2. Зээ mӧдысь: 5

III.А.2. Тун 'колдун': 17

\section{III.Б. Предвидит}

III.Б.1. Предсказывает, знает будущее и прошлое (тӧдлӧма, висьтавльллӧма, шуллӧла, вӧлӧм быдтор тӧдӧ, водзе олэлтэ висьтальщтэ): 1, 2, 3, 5, 8, 16, 17, 18, 19, 20, 22, 24, 25 (IV.A., Б., Г)

III.Б.2. Указывает на счастливые / несчастливые дома / места: 3, 15, 20, 21 (IV.B.)

III.Б.3. Предсказывает приход в полночь умершей знающейmӧдысь: 9, 22, $26(\mathrm{~V})$

III.Б.4. Предсказывает свою смерть: 8, 19 (VI.Б.)

\section{III.В. Воздействует словом}

III.B.1. Останавливает лодку другого знающего-тӧдысь: $6,7,8$ (VII)

III.В.2. Перегораживает путь крысам на Вишеру: 1, 2, 4, 10, 11, 12, 19, 22, 29 (VIII)

III.B.3. Может заколдовать удачу в охоте, поэтому охотники не смеют спорить с ним: 19

\section{III.Г. В воде не тонет}

III.Г.1. Ныряет, проплывая большие расстояния под водой: 13, 19, 21, 22, 23, 28 (IX)

III.Г.2. Ловит руками рыбу: 19

III.Г.3. Абу морт рӧд ‘нечеловеческого рода': 23 


\section{IV. ПРЕДСКАЗАНИЯ ТЮВЭ:}

IV.A.1. Наступит конец света, жизнь разладится, будет плохая жизнь 'му вежандыр, олӧмыс поласяс, олӧмыс регыљ / дженид лове, олӧмыс торксяс'

IV.A.1.1. В 2012 г. наступит конец света от наводнения или огня, останется одна женщина 75 лет, она будет руководить миром; выжившие останутся на самолёте: 1

IV.A.1.2. Будут убивать:

IV.A.1.2.1. Брат сестру, сын отца: 1

IV.A.1.2.2. Человека на крыльце своего дома: 2, 3

IV.A.1.2.3.1 На каждом крыльце будет труп: 17

IV.A.1.2.3.2. На каждом крыльце будет труп, но хоронить будет некому: 5

IV.A.1.2.4. Будут крыльцо на крыльцо драться: 20

IV.A.1.2.5 Будет война с Севера: 14

IV.A.1.3. Исчезнет мужской род:

IV.A.1.3.1 Бабы будут бросаться на подпоясок от мужских штанов: 14

IV.A.1.3.2. Захочется лечь в могилу вместо матери, потому что останутся одни вдовы, некому будет дрова заготавливать, возможно после войны: 20

IV.A.1.4. Исчезнет рыба в реке и дичь в лесу: 18

IV.A.1.5. Будут поджигать бересту, обёрнутую вокруг голени, и в воду не пустят: 25

IV.A.2. Когда наступит конец света, жизнь разладится, будет плохая жизнь

IV.A.2.1. В 2012 г.: 1

IV.A.2.2. После недолгой хорошей жизни: 1, 2, 8, 11, 12, 25

IV.A.2.3. Когда будут летать железные птицы: 1

IV.A.2.4. Когда всё село окутает паутиной: 8, 18, 19, 22, 25

IV.A.2.5. Когда с абажура будут петь: 19

IV.A.2.6. Когда брёвнами перегородят р. Нившера около дер. Тист: 28

IV.A.2.7. Когда исчезнет рыба в реках и дичь в лесу: 18 
IV.A.2.8. Когда Троицк станет городом: 11

IV.A.2.9. Когда соединятся с. Нившера и дер. Тист: 27

IV.Б. Жизнь поменяется, будет что-то новое:

IV.Б.1. Будут летать железные птицы - самолёты: 1, 24

IV.Б.2. Село / дома окутает паутиной - электросети, радио, телефон: 8, 16, 17, 18, 19, 20, 22, 24, 25, 27

IV.Б.3. С абажура будет слышно пение - радио: 19

IV.Б.4. На р. Вишера будет железный пояс - мост: 16

IV.Б.5. Построят фрабрику-завод: 16

IV.Б.6. Все будут есть хлеб с одной квашни: 16

IV.Б.7.1. Троицк будет городом: 11,12

IV.Б.7.2. Богородск будет городом: 20

IV.Б.8. Дорога соединит Богородск с миром: 20

IV.B. Указывает на счастливые / несчастливые дома / места:

IV.B.1. В местечке Борганшор жизни не будет: 3

IV.B.2. Указывал на места для строительства дома: 15

IV.B.3.1. Указал на три несчастливых дома в Богородске: 20

IV.B.3.2. Указал на три несчастливых дома в Богородске, в том числе на дом информанта: 21

IV.Г. Сбывшиеся предсказания:

IV.Г.1. Будут летать железные птицы - летают самолёты: 1, 24

IV.Г.2. C абажура будут петь - появилось радио: 19

IV.Г.3. Все будут есть хлеб с одной квашни - покупаем хлеб в магазине: 16

IV.Г.4. На р. Вишера будет железный пояс - построили мост через р. Вишера: 16

IV.Г.5. В указанном месте будет завод - построили электростанцию: $16,18,19,20$

IV.Г.6.1. Окутает паутиной - провели радио, протянули электросети: 3, 16, 17, 19, 20, 24

IV.Г.6.2. «Село окутает паутиной, но хорошая жизнь будет недолгой» - как провели электросети / провели телефон, началась война: 8, 22 
IV.Г.7. Людей будут убивать на крыльце своего дома в дер. Зулэб на крыльце бани убили человека: 3 IV.Г.8. На каждом крыльце будет труп - так Тювэ предсказывал войну: 5, 17.

IV.Г.9. Недолгое существование электростанции: 15

IV.Г.10. В местечке Борганшор жизни не будет - дома пустуют, жителей нет: 3

IV.Г.11. Указал на три несчастливых дома в Богородске жизнь хозяев этих домов не сложилась: 20, 21

IV.Г.12. Не сбылось предсказание Тювә о том, что жизнь закончится, когда брёвнами перегородят реку около дер. Тист: 28

\section{V. ТювЭ и ТӦДЫСЬ: 5, 9, 22, 26}

V.A.1. В полночь собака Тювэ своим лаем не дала перейти по жерди через ручей к дому Тювэ другому знающему-тӧдысь (ьљжыд тӧдысь, женщина), который хотел его убить: 5

V.A.2. Приказал собаке (по кличке Соболь?) не пропустить перейти по мосту Марбя-лал, знающей-тӧдісь из Большелуга, которая якобы должна умереть сегодня и в полночь придёт к Тювэ, чтобы его съесть. В этом случае она пойдёт в обход через верховья реки, а за это время взойдёт солнце, и она уже не сможет съесть Тювэ: 22

V.Б.1. Тювэ пустил двух вылибских [деревня в Большелугском с/с] охотников в лесную избушку в Мартестане. Те сообщили (он им сказал?) о смерти Сюзь Матрен из Большелуга. Эта женщина была подругой Тювэ, но он не взял её в жены, за что Матрен пообещала прийти после смерти и съесть его. Тювэ ожидает её приход в полночь и предполагает, что Матрен не сможет перейти по мосту, потому что её обули в новые коты, и будет скользко. Она пойдёт в обход, и её время истечёт. В полночь собака залаяла и, облаивая Матрен, пошла в обход реки: 26

V.Б.2. Чтобы защитить себя от умершей сухоногой колдуньи, которая должна была прийти к нему в полночь, Тювэ облил мост водой: 9 


\section{VI. ТЮВЭ И ЖЕНА: 8,19}

VI.A. Тювэ предупредил жену, чтобы та не боялась его после смерти. Он лёг умирать на печь, а после смерти встал и рассказал, что его деньги лежат под корнями дерева: 8

VI.Б. Перед смертью Тювэ просил жену уйти из дома. В полночь он встал из гроба и стал искать жену. Та сидела на печи, очертившись угольком. Услышав лай собаки, Тювэ лёг обратно в гроб: 19

\section{VII. «СУСЛО, СТОЙ»: 6, 7, 8}

VII.A.1. Тювә варил пиво, другой знающий сплавлялся на лодке, Тювэ остановил лодку, второй - пиво; состязались на словах: 6

VII.А.2. Тювэ крикнул большелугскому человеку / знающему, сплавлявшемуся с сеном мимо Тювэ керес, «лодка, стой»; тот в ответ крикнул жене Тювэ, варившей пиво, «чан / сусло, стой»: 7, 8 .

VIII. ТЮВЭ И КРЫСЫ: 1, 2, 4, 10, 11, 12, 19, 22, 29

\section{VIII.A. Тювэ перегородил путь крысам}

VIII.A.1.1. На Вишере нет крыс, потому что так сказал / сделал Тювэ (шулэла / керлэла): 2, 19, 29

VIII.A.1.2. Тювэ на сто лет перегородил крысам путь на Вишеру: 10

VIII.A.2.1. Тюве наказал крыс за то, что они съели у него мешок сухарей: 22

VIII.A.2.2.1. Тювэ перегородил крысам дорогу на Вишеру за то, что они съели его обед из вещмешка, когда он, возвращаясь пешком из Сторожевска, сел отдохнуть в местечке Гӧрд чой: 1

VIII.A.2.2.2. Тювэ перегородил крысам дорогу на Вишеру за то, что они съели его обед из вещмешка, когда он, возвращаясь на лодке из Сторожевска, вышел на берег отдохнуть в местечке Гӧрд чой: 4

VIII.A.2.2.3. Тювэ перегородил крысам дорогу на Вишеру за то, что они съели его обед, когда Тювэ, поднимаясь с грузом по Вишере, вышел пообедать в местечке Гӧрд чой, разложил обед на пне и спустился к лодке: 11 
VIII.A.2.2.4. Тювэ перегородил крысам дорогу на Вишеру за то, что они съели его обед в местечке Ростагъя / Гӧрд буджед, когда он поднимался по реке на барже: 12

\section{VIII.Б. Тювэ перегородил крысам путь в местечке}

VIII.Б.1.1. Гӧрд чой: $1,2,4,11$

VIII.Б.1.2. Гӧрд буджӧд: 12

VIII.Б.1.2. Мусюр: 2, 19

VIII.Б.1.3. Шудӧг: 10

VIII.Б.1.4. Ростагъя: 12

VIII.Б.1.5. Джиян пос 'мостик через ручей около дер. Ивановской': 29

VIII.B. В результате перечисленных действий в указанном месте крысы выпрыгивают с баржи, парохода, поднимающегося по р. Вишера: 1; 2, 10, 11, 12, 19, 22, 29

VIII.Г. В селениях по Вишере крысы не водятся, возможно, по другим причинам:

VIII.Г.1. Из-за растения сипертас (маръямоль) 'марьин корень, дикий пион': 2, 22

VIII.Г.2. Из-за недавно найденной урановой руды: 10

ІХ. ТЮВЭ ПЕРЕДВИГАЕТСЯ ПОД ВОДОЙ: 13, 19, 21, 22, 23,28

IX.А. Тювэ может проходить большие расстояния под водой, ловит руками рыбу: 19

IX.Б.1. Тювэ ныряет около дер. Лунь, выныривает в Пӧлян кӧтшас: 13

IX.Б.2. Тювә ныряет в Богородске, выныривает около Сторожевска: 21

IX.Б.3. Тювэ ныряет в Тисте, выныривает около Боровска: 28

IX.B.1.Тювэ ныряет в Нившере, выныривает в Розтагъя, опасаясь быть проглоченным щукой, в другом месте - от невозможности пройти через стаю налимов, стоящих сплошняком: 22 
IX.В.2. Тювэ ныряет в Нившере, проплывает по рекам Нившера и Вишера, но выныривает, не дойдя до Богородска, поскольку там реку перегораживает щука: 23

\section{Х. ТЮВЭ И ДРУГИЕ МЕСТНЫЕ ГЕРОИ:}

Х.А. В газете писалось, что Тювә ходил к Ленину просить хлеб. Ходил не Тювә, а Епим - он разбойничал, и из-за него все вишерские прославились разбойниками, их не пускали на ночлег: 22

Х.Б. Тювә и Тист Иван ${ }^{1}$ - один и тот же человек: 29

\section{XI. ЭТНОГРАФИЧЕСКИЙ КОНТЕКСТ:}

XI.А.1. О Тювэ рассказывали / вспоминали предки (важљя йӧз): $9,11,12,16,21,26$

XI.А.2. О Тювә рассказывала мама/бабушка: 3,17

ХІ.Б.1. О Тювә рассказывали женщины, обсуждали, что сбываются его предсказания: 3,5

ХІ.Б.2. О Тювә рассказывают, когда говорят об отсутствии крыс в бассейне р. Вишера: 1

ХІ.Б.З. О Тювә рассказывали пожилые люди во время сенокоса в тех местах, где жил Тювэ: 16

ХІ.В. О Тювэ рассказывают нившерские: 21

ХІ.Г. О Тювэ рассказывал ямщик: 11

ХІ.Д. О Тювә писали в газетах: 12,22

ХІІ. ТЕКСТЫ ПРЕДСТАВЛЯЮТ МИКРОЛОКАЛЬНУЮ ТРАДИЦИЮ СЕЛА:

ХІІ.А. Большелуг: 1-4

ХІІ.Б. Богородск: 5-21

XII.В. Нившера: 22-29 
1.

Тювӧьљ вӧллӧма, Висер сайин. Сія Висерсянь, кьлин километра сайин сія и оолӧма - Тювӧ кӧджӧн шувень. Тювӧд оолӧма. И Тювӧььс сія ставсӧ тӧдлӧма.

Вот, двухсот двенадиатой годьн пе тая быре олӧмис, тайӧ му выьысыьс. Или же пе быре ва или же бийен. Истав мир пасьтаыс пе коле, Тювӧд шулэма, ӧти морт женсина, сизилдас вит арӧса, пондас ставнас руководитні, став мирнас. Двухсот девятый годын пе тая олӧмыс быре. Сія Тювӧд шульлллӧма [...].

А мортсӧ пӧ пондас вині, вокыс пӧ чойсӧ пондас вийні, пиис пондас батьсӧ вийні. Лове пӧ сэтшӧм олӧмыс. Мортсӧ пӧ пондасні вийні - Тювӧд шульлллӧма. Ог тӧд, ся сія збылль ли оз ло [...].

Тювӧс сійӧ мьйкекерас, кьıтчӧкӧ ветлас нопиен. Лэччылас подэн кылчӧкӧ Шойнатыю̈ ли кытче. И сія сэсся Гӧрд чое унмоосяс. Сәсся крысад сылысь нопсьыд сёяс сёянтӧ. Сэсся шувас: "Тэнід пе таььсь водзе Висер вожӧ кайні туйыд оз ло!» И тані пе крыса ни нинӧл абу. Весиг пӧ вӧлі параходьяс вылад да баржа вылад крысаясыљ пондасны кайны да, ставыс пӧ Гӧрд чое воасны да чеччаласны сэсся юас. Берегас вуджасні, юас чеччаласні да. Тайӧ висьтоолісні, мый Тювӧд шулӧма [...].

А кӧрт лэбачтӧ-сія салолёттӧ висьтоолӧма. (Р: А ешшё мый висьталӧма, мый лоас?) Но сэсся, сәсся сія тай шувела: олӧмыс пӧ сэтшӧл лове, пондасны пӧ кӧрт
Тювэ был некогда за Богородском, от Богородска в скольких [же] километрах он и жил - называют [место] Тювэ кӧдж ${ }^{2}$. Тювэ жил. И этот Тювэ всё знал.

Вот, в двухсот двенадцатом году эта жизнь закончится, мол, на этой земле. Закончится водой или огнём. И во всем мире останется, Тювэ сказывал, один человек женщина, семидесяти пяти лет, будет всем руководить, всем миром. В двухсот девятом году, мол, эта жизнь закончится. Это Тювэ говорил [...].

А человека будет убивать, мол, брат будет убивать сестру, сын будет отца убивать. Будет, мол, такая жизнь. Человека, мол, будут убивать - Тювэ предсказывал. Не знаю, это вправду будет или нет [...].

Тювэ этот куда-то сходит с котомкой. Сходит пешком куда-то в Сторожевск или ещё куда. И он потом в [местечке] Гӧрд чой уснёт. Потом крыса у него из котомки съест еду. Потом скажет [Тювэ]: «Тебе, мол, дальше этого места в верховья Вишеры дороги не будет!» И здесь ни крыс и никого нет. И даже когда было поднимаются на пароходах и баржах, как только к [местечку] Гӧрд чой подойдут, все крысы спрыгивают в реку. К берегу добираются, выпрыгнув в речку. Это рассказывали, что Тювэ сказывал [...].

О железных птицах - про самолёты предсказывал. (Р: А что ещё предсказывал, что будет?) Потом он ещё вот сказал: жизнь такая 
лэбачьяс лэбооні, но и олӧмыс абу пӧ кузь. Кьљк тыссяча да дас кькӧд воьин пе быре тая земляыс. Тая зелляыс пӧ ставыс быре, и коле пе, став му пасьтас кытчекӧ пе колены йӧзыс, да пондас сизимдас вит арӧса баба руководитні. Но йӧзыс пӧ этша коле. Сія Тювӧ шулӧма. Вот, сэсся двухсот двенадиатӧй год только виччысь. А этша йӧзыс, коді коле? Кодлэн выйим салолёт, да кыпедчині вермас, пондас кӧ ставыс ойдні да бийен сотчині, сэтшӧльс и спаситчас. А ӧстальнӧйыс ставыс пӧгибнитас. будет, мол, будут железные птицы летать, но и жизнь [будет] не такая длинная. В 2012 году, мол, исчезнет эта земля. Эта земля, мол, полностью исчезнет, и останется, мол, по всей земле где-то останутся люди, будет 75-летняя женщина руководить. Но людей мало останется. Это Тювэ говорил. Вот, потом только 212-ый год жди. А мало людей - кто останется? Те, у кого есть самолёт, и смогут взлететь, когда всё вокруг будет заливать водой или гореть огнём, такие и спасутся. А все остальные погибнут.

Зап. А. Н. Рассыхаев 06.01.2011 в с. Большелуг от Игушевой Анастасии Спиридоновны, 1919 г. р.

\section{2.}

Шувӧньь, кутшӧлкӧ турын пе выйим, сипертас шувені, сьылэні и быцдээн, сипертассэ. Сія турынысс пӧ сыльь прӧтивнӧ, крысаыслль-я. Ог тӧд, ся сія ли абу. Важ йӧз шульлллӧмась, тӧдысь йӧзбяс вӧлӧмась да, татчӧ пӧ сія оз ооледчи. Кутшӧмкӧ тӧдысь, Тювӧӧн тай вӧлі нимтэні пея. Сія пе шуве: татче пе сія оз оомедчи, оз пе лок. Оз пе лок. Бара няньястӧ баржаяснад вӧлі войдӧртӧ ваені да, юас пе и чеччалэні крысаясыс баржа выьыссьыс. (Р: А кӧні чеччалӧнь??) Мусюр, Гӧрдчойӧн шувені, Шойнатысяньыс локні кутан да, сэтче кыйлин пе-й чеччалӧні баржасьыс. Ваас пе и чеччалэні. [...] Олӧлыс торксяс, тшыксяс пе,
Говорят, какое-то растение есть, марьин корень ${ }^{4}$ называют, песни поют даже про него. Это растение, мол, ей, крысе, противно. Не знаю потом, это [растение] или нет. Старые люди рассказывали, знающие люди они были, здесь, мол, крысы не приживаются. Какой-то mӧдьıсь-знающий, Тювэ его звали. Он говорил: здесь, мол, крысы не приживаются, не идут [сюда]. Не идут. Раньше хлеб на баржах привозили, в реку крысы выпрыгивали с баржи. (Р: А где выпрыгивали?) На [возвышенности] $M y$ сюр $^{5}$, Гӧрд чой ${ }^{6}$ называют, когда со Сторожевска поднимаешься, там примерно и выпрыгивают крысы с баржи. В воду и выпрыгивают. [...] Жизнь разладится, испортит- 
да морттӧ кутасні содка помас виёвні. Ӧні пӧ эськӧ бура оланньц да, олӧмыд пӧ торксяс на. ся, и человека будут на крыльце своего дома убивать. Сейчас, мол, хорошо ещё живёте, но жизнь ещё разладится.

Зап. А. Н. Рассыхаев 05.11.2010 в дер. Зулоб Большелугского с/с. от Игушевой Евдокии Николаевны, 1934 г. р.

\section{3.}

Тювӧсӧ эськӧ ме ог тӧд, код сэтшӥмыс. Но тӧда, мый сійӧ миянльсь этаті Борганшор дорсӧ шульллӧма мунігас. Сэті збыльысь мича местаясыс да: "Ок пӧ, мича местаыс да олӧмыьс некор оз ло». И сэні керкаясьц, ӧні том йӧзыс оз и пуксьыны весиг, потому что сэні керкаясыс ставыс нин пустуйтӧньь. Но водз кулалӧны йӧзыс, абу кузь немась. Пӧчӧ тай Тювӧӧс жӧ вӧлі висьтавлӧ-а. Менали челядьдырйи на вӧлі висьталӧ Тювӧсӧ. Вӧлі бабаяс мыйкерасны, чукӧртчасны, сійӧ Тювӧ йыьсььљд. Кор радиотӧ кутісньь нюжйӧдльны, вот сэки вӧлі: но вот черань вез, збыльысь тай Тювӧыд шулылліс. Тэсся кор Зулӧбын мортсӧ виисны, пьввсянсьыс петігӧн, пьвсян дорас вӧлі вийӧмась: вот пӧ Тювӧд шуліс, воас пӧ кад, кильчӧ помад пӧ ӧта-лӧдсӧ кутаснь виавны. Вот сы бӧрти ставсӧ сэсся ӧтлаалӧны сәсся.
Так-то я не знаю, кто такой Тювэ. Но знаю, что он говорил про наш Борганшор ${ }^{7}$, когда проходил. Там действительно красивые места: «Ox, красивые места, мол, но жизни никогда не будет». И там дома́, на этом месте молодёжь даже не строится, потому что там все дома пустуют. Рано умирают люди, короткий у них век.

Бабушка <по отцу> тоже про Тювэ рассказывала. В детстве ещё рассказывала про Тювэ. Женщины было соберутся, и про Тюве [вспоминают]. Когда радио стали проводить, вот тогда говорили: ну вот и паутина, правду Тювэ предсказывал. Потом когда в Зулэбе человека, выходя из бани, убили, около бани его убили: вот, мол, Тювэ говорил, придёт время, когда на крыльце будут друг друга убивать. Вот после этого случая стали всё сопоставлять.

Зап. А. Н. Рассыхаев 26.10.2014 в дер. Выльыб Большелугского с/с от Мишариной Ольги Ивановны, 1962 г. р. 
Сійӧ вӧлӧм пыжӧн кайӧ. И сылысь Гӧрд чояс мыйкӧ, нопсьыс, пажнайтны пуксяс, нопсьыљ сёйӧмась крысаясыљ сылысь сёянсӧ. Сэки Тювӧд и шуӧма, скӧрлӧма да: "Таьıсь водзӧ пӧ тіянлы ся туйыс абу!» И сыссянь крыса абу. Шойнатыын эл, миян - абу. Висер вожын крыса абу. Сідз вӧлі висьталӧны-а.
Он на лодке поднимался. И в местечке Гӧрд чой у него, когда он сел обедать, из котомки крысы съели его обед. Тогда Тювэ и сказал, рассердившись: «Дальше этого вам дороги нет более!» И с того времени крыс нет. В Сторожевске есть, а у нас - нет. В бассейне Вишеры крыс нет. Так рассказывали.

Зап. А. Н. Рассыхаев 26.10.2014 в дер. Выльыб Большелугского с/с от Мишарина Бориса Алексеевича, 1959 г. р.

\section{5.}

Тювӧыс пӧ сія эськӧн коркӧ вӧвлӧма. Сійӧ, кӧні Тювӧсӧ висьталӧнь, кӧн сія оліллӧма быттен, сія местас Тювӧн жӧ льљдыьыссе, сы местас. А Тювӧс пӧ сія вӧлӧма зээ тӧдісь. И сылӧн пон вӧлӧма, Тювӧслӧн. А сы дінӧ вӧлӧл локтӧ лиод, но сія шор сайьн вӧлӧм олӧ. Эсся шорӧд колӧ вуджны сы дінӧ, а мӧдыс сія шор саяс вӧлӧма. Ог тӧд, баба, дашкӧ, висьталӧны ли мужик, сія мед пӧрйӧдлӧм оз ло, баба ли коді. Локтӧ вӧлӧм Тювӧс дінӧ. А Тювӧслӧн понйьс, вот тӧда вӧлі нилсӧда вуні, ог нин помнит, мый нила и ел. Понйьс вӧлӧма, да понйьсс вӧлӧм сія мӧд тӧдісьсэ оз лэдз поссэ вуджні. Толькӧ пӧ сёйӧ-сёйӧ-сёйӧ. А сія вӧлӧм мыюрдӧн локтӧ, да Тювӧ шувӧ: "Он лок, он лок!" Но вот вуні нильєс мыйкӧслӧн, понйыслӧн. Сія пӧ
Тювә, мол, когда-то был на самом деле. Там, где о Тюве рассказывают, где будто бы жил он, это место тоже Тювэ называется. А Тювэ, мол, был очень <много / сильно> знающим. И у него собака была, у Тювэ. К нему шёл другой [знающий], а он <Тювэ> за ручьём жил. К нему через ручей надо перейти, а другой [знающий] был за ручьём. Не знаю, женщина, может, говорили, или мужик, чтоб не обмануть, женщина или кто 8 . Он направлялся к Тювэ. А собака Тювэ, вот знала кличку и забыла, не помню уже, как звали. Собака была, и собака того другого знающего не пускала перейти через мост. Только и облаивает, мол <букв.: ест-ест-ест>. А тот упорно пытался пройти, и Тювэ говорит: «Не дойдёшь, не дойдёшь!» Ну вот забыла кличку этой собаки. Она 
кутас, он пӧ лок, он пӧ верли. Абу и вермӧма локны ся сіе. Сія бытте мыйкесьыс на, Тювӧсис на ьцжыц тӧдісь вӧлӧма. Но всё равно абу верлӧма вуджніс шорсэ.

А Тювӧс сія вӧлӧм быдтор тӧдӧ. Даже тая войнаястӧ тӧдӧ вӧлӧл. Гашкӧ, сё во сайьн войнаӧдзыс на, кор вӧлӧма, уна во сайьн вӧлі, сэк нин вӧлӧм тӧдӧ войнасӧ сіе. Былтте йӧзысльь висьтавльвлэма: коркӧ ловӧ пӧ война. Йӧзыс пӧ ёна кулӧньь. Даже пӧ поскапомас шуйьс пӧ ловӧ да некод пӧ оз понды вермыны дзебнысӧ. Тадзи вӧлі сёрнитӧны, но бабаясыљльсь, пӧрысь бабаясыллысь кыьылан сёрнисӧ да. <собака> сдержала, не пройдёшь, мол, не сможешь. Так и не смог тот <знающий> пройти. Он будто бы был более знающим, сильнее, чем Тювэ. Но всё равно не смог перейти ручей.

А Тювэ тот обо всём знал. Даже об этих войнах знал. Возможно, за сто лет ещё до войны, много лет назад это было, тогда уже он знал о войне. Будто людям он рассказывал, что когда-то будет война. Людей, мол, много умрёт. Даже на крыльце будут трупы лежать и, мол, никто не сможет похоронить. Так говорили, у женщин, пожилых женщин слышала разговоры эти. ${ }^{9}$

Зап. А. Н. Рассыхаев 09.06.2012 в с. Богородск от Солодовниченко Марии Филипповны, 1926 г. p.

6.

Мӧдыс вӧлі ю кузя кыььтӧ, кыьıтӧ вӧлӧм пыжӧн, кыьытӧ, Висер кузяс вӧлі кыьытӧ да. Сэсся ог тӧд мьıйьссь, венӧ усьӧмась. "Лодка пӧ стой!» - Тювӧс шувӧма. Ся кьвтыссь мортыдлӧн пыжыс пондӧма места вылас бергавны. Оз пӧ кыьыт, прӧстӧ пӧ бергалӧ.

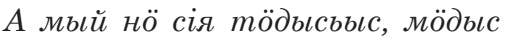
шувӧма ӧтветсӧ Тювӧвьсль? Мыйкӧ жӧ шувӧма Тювӧьсльь. Ог тӧд. Ся найӧ, кык тӧдыєсь, верласьӧмась сёрниӧн быттьӧ. Мӧдыс ог тӧд мый. Сур пӧ пуӧ
Другой [человек] по реке сплавлялся, на лодке сплавлялся, по Вишере сплавлялся. Потом, не знаю отчего, заспорили. «Лодка, мол, стой!» - Тювэ сказал. Потом у сплавляющегося человека лодка стала на одном месте крутиться. Не идёт, мол, просто крутится. А что же тот знающий, другой сказал в ответ Тювэ? Что-то же сказал Тювэ. Не знаю. Потом они, два знающих, состязались на словах. Другой не знаю, что [сказал]. Пиво варил, мол, да может пиво 
да, гашкӧ, сурсӧ суутӧдӧма да: "стойнас!" мӧдьсс да. Тювӧс вӧлі сур пувӧ $\partial а$. остановил, крикнув «Стой!». Тювэ ведь пиво варил.

Зап. А. Н. Рассыхаев 09.06.2012 в с. Богородск от Панюковой Лидии Михайловны, 1940 г. р.

7.

Тӧдысьыљ татӧні миян эз ёна вӧо̆, Ыджьљвидзьясад уна. Ӧти миян тані, Тюве керӧс эстӧні кызь километра сайын, Тюве керӧс выйим. Тюве керӧсас тӧдысь вӧлӧла. Да сія вӧлӧм ьцжьдвидзса кодкӧ турун доддьӧн лэчче, турун пьжӧн да "лодка пӧ стой". "А лодка кӧ пӧ стой», а бабас вӧлӧм сур пувӧ да мый сія шусьӧ станььс, тшан, тшан, тшан, "тшан пӧ стой». И сія сувтӧма жӧ. Лодка кӧ пӧ стой, тэнад пӧ тшӧтш. Тӧдысьясыд миян эз ёна вӧӧ. Тювеыс сія локтӧм морт жӧ нин, кыськӧ локтлӧла, гозйӧн локтӧма. (А кысь локтӧма?) Увланьыссь, увланьыссь локтӧма. Увланяд эд йӧзыц тӧдӧныцжык.
Знающих у нас здесь немного было, в Большелуге там много. Только один у нас..., Тювә-возвышенность там в двадцати километрах отсюда, Тювә-возвышенность есть. В Тювэ-возвышенности знающий жил. И один большелугский сплавлялся с сеном, с сеном на лодке, [Тювэ крикнул], лодка, мол, стой. «Если лодка стой», а жена [Тювэ] варила пиво, и как этот стан называется, чан, чан, чан, - «чан стой», мол. И [пиво] тоже остановилось. Если лодка стой, то, мол, у тебя тоже [стой]. Знающих у нас немного было, и Тювә пришлый человек тоже, откуда-то пришёл, вместе с женой пришёл. (А откуда пришёл?) C низовьев, с низовьев [реки] откуда-то. В низовьях люди более знающие.

Зап. Л. С. Лобанова, А. Н. Рассыхаев 08.06.2012 в с. Богородск от Игушевой Марии Семёновны, 1923 г. p. 
8.

Вольвлэма, эстэні Тюве на вольвлэла ий. Сэтэні кызь ӧти килолетра сайьн Тюве на овледчылэла, кыське локтэл морт же, тӧдысь же вӧлэма, тӧдысь. Кодке ьджыдвидзса вӧлэл лэчче, да Тювеыд шувас: лодка пе стой. Лодка ке пе стой, бабас вӧлэл сур пуве, да ме ог тӧд, сурсэ мьен сіес и шувема (суслоэн оз шунье) Сусло стой пе же. Дугдэла тиӧти, сія кьк тӧдысыьд вӧлэл мыйкекерены. Сэсся лэдзела же, корке мунэла же. Лодка пе стой. Кьк тӧдысь вӧлэлаэсь. Мыйке эськи Тура Петыл Миш Иваныс куччьссьліс каттыьсльны сэтчи да эся ачьєс кулі. (Панюков Иван Михайловичьє?) Да, сія ёна вӧлі интересуйтче Тювенад. Бабаысль Тювеыс вӧлэл шуве: ме пе сэсся кула, эн пе меысь пов. Кулэла да кулэл бӧрьяыс на чеччылэла-й быдсэн. Кулэла на, да, дерт, лольс эз на пет, чеччылэла на, чеччылэла на, чеччьллэма. Кьське деньгаяс на висьталэла, уна-уна деньга на вуж ульєсь ли кыцсь, былдсяласэ на висьтавлэла бабаысль кулігас Тювес. Кьк локтэл йӧз вӧлэлась. Тювеьс, сэтэн керес, кызь ӧти килолетра сайьн иор выцйьл, мыйкес сэтче овледчьлэла чой йьлас, Пукдылм, шорьсллэн Пукділпьтши, а сія овледчьсьыс Пукдім дзик сія мыйке вылас овледчылэла, Тюве керес. Ӧні нинэл нин абу. (Скӧт видзлэла?) Скӧт и ставсэ, быдсяласэ видзлэла, озыр вӧльвлэла
Приезжал, туда вот и Тювэ приезжал. Там в двадцати одном километре отсюда Тювэ когда-то жил, откуда-то пришлый человек, тоже знающим был, знающим. Один большелугский сплавлялся, Тювэ сказал: лодка, мол, стой. А если лодка стой..., жена [Тювэ] варила пиво, я не знаю, как он уж назвал пиво. (Суслом не называют?) Сусло, мол, тоже стой. И остановилось, это двое знающих [боролись]. Потом отпустил, когда-то отпустил. Лодка, мол, стой. Двое знающих было. тура Иван Михайлов сын Петров внук брался за него, но сам умер. (Панюков Иван Михайлович?) Да, он очень интересовался Тювэ. Жене своей Тювэ говорил, когда я, мол, умру, ты меня не бойся. Умер, и даже после смерти ещё вставал. Умер, но, конечно, душа ещё не вышла, вставал ещё, вставал. Рассказал, что где-то деньги лежат, много-много денег под корнями ли где-то, много чего рассказал жене при смерти. Вот два пришлых человека были. ${ }^{10}$ Тювэ..., там есть возвышенность и ручей в двадцати одном километре отсюда, он там обосновался на пригорке, Пукдым называется ручей, а он обосновался на возвышенности возле ручья Пукдым, на Тювэ-возвышенности. Сейчас там уже ничего нет. (Скот держал?) Скот держал, и всё у него было, богатый пришлый человек был, богатый, богатый человек, богатый купец. (Говорят, он будущее предсказывал?) О будущем гово- 
локтэл морт, озыр, озыр морт, озыр купеч. (Мыйке кужема пе водзе олэлсэ висьтаны ?) Водзе олэмтэ висьтышталэ, оз пе ёна. Корке пе, сэки вед биясыљ эз на вӧӧ, корке пе ставыс вӧлӧсьтас вез лове, но бур олэлыд пе сэки регыљ лове. Бур олэлыљ тай регид и лови, сәсся войнатэ паніснь, Отечественнэйтэ. Регыд пе бур олэлыс лове. Висьталэ пе вӧлі, висьтышталэ. Тюве сія тӧдысь вӧлэла, ставсэ тӧдэ вӧлэм, водзысь олэм дай, бӧре колелтэ сія, дерт, нин тӧдас, водзе олэлсэ тӧдэ вӧлэл, сэтшел тӧдысь морт вӧлэма, татче вольвлэла, ог тӧд мыйла. (Гӧтырсэ водзвыьв велэдэла, мед оз повзыь сыьысь?) Мед оз повзыьь, ме пе кула, может пе ме чеччыла на, эн пе пов меысь, ме пе тэнэ нинэл ог кер, ог пе вӧред, бӧр пе места вылэ вода и кула. Дерт, сэтче дзеблісны, эз, дерт, вайны татче, сэтче-й дзеблісны сіе. (Сія гусьыс чеччыләла?) Абу, паччер вылас кувны водэла, тавун пе ме вода кувны паччер шӧре. Кула пе, эн пе пов меысь, ме пе тэнэ нимен ог кер, ме ловзыьла на, ловзыыла да сёрнитышта на пе тэкед. Ловзььлэла и сёрнитэла на вот, сэсся бара кулэла. (Мый виьталэла?) Ог тӧд, но олӧльястэ висьтышталэла на maŭ вот. рил, но немного. Когда-то, мол, тогда ведь электричества ещё не было, когда-то, мол, на селе кругом паутина будет, но тогда хорошая жизнь будет короткой. Хорошая жизнь недолго и была, началась война, Отечественная. Ненадолго, мол, хорошая жизнь наступит. Рассказывал, мол, немного рассказывал. Тювэ он был знающим, всё знал, будущее знал, а прошлое, что уж там, конечно, знал, будущее знал, таким знающим был, сюда переехал, не знаю почему. (Жену заранее предупредил, чтобы она не пугалась?) Чтобы не пугалась, я, мол, умру, и может ещё и встану, не бойся, мол, меня, я тебе ничего не сделаю, не трону тебя, обратно на место лягу и умру. Конечно же, его там и похоронили, не привезли же сюда, там и похоронили. (Он из могилы вставал?) Нет, на печку лёг умирать, сегодня, мол, я лягу умирать на лежанку печи. Умру, мол, но ты не бойся меня, я тебе, мол, ничего плохого не сделаю, я оживу ещё, оживу и поговорю ещё с тобой. Ожил, и поговорил ещё, и снова умер. (О чём рассказал?) Не знаю, но о будущем говорил.

Зап. Л. С. Лобанова 12.06.2012 в с. Богородск от Игушевой Марии Семёновны, 1923 г. p. 
9.

(Вӧлэма кутшелке Тюве?) Тювеыл сія Висерын, абу татэн, сія ю дорас Висер йьлас. Корке, висьтоласны важ йӧзыд, мыйке восьтэла..., содъяс, Тюве: час пе тавун пета да мыйке час кӧдзыд, кӧдзыдэн ю поссэ пе кӧтӧда. Тавун пе локтэ, ог тӧд мый нима, тӧдысь локтэ. Кос кокнас локтэ пе да, мед пе вильдас да усе. Войшӧр гӧгӧр кымлын пе ме дінэ пондас локнь. Пос пе кисьталас, тӧдысь пе вой шӧр гӧгӧр кылын..., кулэла нин да локтэ, катшке пе катшке. Он пе пыр, поссэ пе кисьталэма, шорас пе усян. Висьталььсьыд тай век эм кодке, Тюве пос сэтэні вӧлэла. Но вот Господи благӧслӧвит. (Эг гӧгӧрво, кутшел пос киськалэма?) Поссэ, олэ, шор вӧлэма сэті аслас вуджан доре, кӧнке Висер йылас, вӧрас ю. Висерас каян, да сылль керкас вуджаніныс пос лэчче, вот Тюве пос, шулэні Тюве пос доре пе ветлім таво. Мый нима нэ, тӧда вед вӧлі, кулэлен сія бабасэ висьталэ, тавун пе сія кулі, пета пе да поскес кисьтала, кос кокыс пе кутас ме дінэ вуджны.
(Говорят, какой-то Тювэ был?) Тювэ был в Богородске, не здесь, там около реки, в верховьях Вишеры. Когда-то, старые люди рассказывали, открыл [дверь], настил..., Тювэ [говорит]: сейчас, мол, я выйду, а на улице было холодно, в морозы мост через реку полью. Сегодня, мол, придёт, не помню как звали, колдунья придёт. С отсохшей ногой придёт, и чтоб подскользнулась. Около полуночи будет идти ко мне. Мост обольёт, колдунья около полуночи [придёт], умерла уже и идёт, стучит-постукивает. Не пройдёшь, мол, мост облит, упадёшь в ручей. Всегда найдётся рассказчик, был там Тювэ-мост. Но и вот Господи Благослови. (Не поняла, какой мост облил?) Мост, где он жил, там был ручей, но и чтоб к себе перейти, где-то в верховьях Вишеры, в лесу. По Вишере поднимешься, и чтоб перейти к нему, мост спускается, вот это Тювэ-мост, говорят ещё, в этом году, мол, ходили к Тювэмосту. Как уж её звали, знала ведь, сказал, что она умерла, сегодня, мол, она умерла, выйду, мол, и оболью мост, сухоногая она будет переходить ко мне.

Зап. Л. С. Лобанова 10.06.2012 в д. Троицк (Типӧсикт) Богородского c/с от Подоровой Анастасии Харитоновны, 1916 г. р. 
А шулӧма [Тюве]: сё во кежлӧ пыкӧма мыйкӧс Висер вожас, крысаясӧс. А сё воьсс коли нин, да крысаыд век абу. Ме думайта да, мыйкеысь висьталӧні, коркӧ воддза вонас буритчисні тай Шудӧгысь, Шудӧгын пӧ выщка эм, и аддзӧмась пӧ кутшӧмкӧ уранӧвӧй руда. Навернӧ, сіе крысаясыљ сіен оз кайны Висер вожад. Сіе Шудӧг весьтас параход вылыссь пӧ вӧлі, висьталӧні менылм лок мысти мыйке, Висер вожӧ пӧ пырал, и крысаясыс пӧ ӧблзательнӧ сэтчи, воам да, чеччавні пондасні.
А сказал [Тювэ], и на сто лет перегородил крысам дорогу на Вишеру. А сто лет уже прошло, а крыс всё нет. Я думаю, говорят, как-то в прошлые годы бурили в Шудоге $e^{11}$. В Шудоге вышка есть, мол, и нашли какую-то урановую руду. Наверно, крысы из-за этого не поднимаются на Вишеру. Около Шудог, мол, с парохода, рассказывали мне после моего приезда [в Троицк], как только на Вишеру свернём [с Вычегды] и доедем [до Шудога], крысы обязательно там будут выпрыгивать.

Зап. А. Н. Рассыхаев 11.06.2012 в дер. Троицк Богородского с/с от Габовой Анны Николаевны, 1936 г. р., уроженки дер. Нижний Воч Усть-Куломского р-на. С 1955 г. проживает в Троицке.

\section{1.}

Тювӧ сія висьталӧні. Миян Анна тьӧтка вӧлі, сія вӧлі висьталэ. Тювӧс сія вӧлӧм грузӧн кайӧ ва катчес. Сэсся сэчче, Гӧрд чойӧн шувӧні, Шойнатьас кӧнкӧ эл, шувӧні Гӧрд чойӧн, сэтчӧ сіе суутас пажнайтні. Пьюжсӧ суутӧдас ю дорӧ, ся каяс, мыйкӧ вылӧджык каяс да ся мыьр вылӧ сёянсӧ пукталэ. Ся мыйке вунӧдас пыжас да лэччас мыйке пыжад. Сэк кості крысад ставсэ сёйӧма нянь, сёянсэ сылыьсь. Сэсся сійӧ чернад мырбяд сатшкас: "Сэсся пӧ тавьсь водзӧ он верльь некытчӧ кайні!» Вот сэсянь миян Висер вожад крысаьљ и абу.
Тювэ, о нём рассказывают. У нас тётка Анна была, она рассказывала. Тювә с грузом поднимался по реке. Потом там, Гӧрд чой называют, в Сторожевске где-то есть местечко, Гӧрд чой называют, там он остановится по обедать. Лодку остановит у берега, поднимется [на берег], выше поднимется и на пне еду разложит. Забудет что-то в лодке и спустится к лодке. В это время крыса съест весь его хлеб и еду. Потом он <Тювэ> вонзит топор в пень: «Далее этого места, мол, не сможешь подняться [по Вишере]!» Вот после этого у нас на Вишере крыс и нет. (Р: После 
(Р: Сэсся ни ӧти абу крысаыд?) Ни ӧти. Вот баржанад вӧлі важӧн ставсӧ вайӧні Одьбъясад прӧдуктатӧ сельподль ий, колхозыдль ӧтрубъястӧ ий, ставсӧ вӧлі баржан вайӧні. Висер юӧ пӧ мыйӧн пыран, ставыс пӧ чеччаласні, ӧтик оз коль. Ниӧтчыц эз воль, вот кылмын баржа воліс да шу, тан коркӧ ӧти воліс - ни ӧти эз. Сійӧ тӧдісь сэтшӧм вӧлӧма [...].

Сія вот кыьылі, мыйке. Ӧтик миян, Ӧгрӧ Иван Домна вӧлі шусе. Да сія вӧлі колльысе Одыбедз вӧлі катӧдас кодӧскӧ да ваяс Одьбсянь да. Менам верӧсӧй коркӧ ськӧд локтӧма Одьбсянь, да сія висьталэма: Тювӧ пӧ шулэла, мыий Типӧсикт пе кар кодь лове, мыйке. Шутем пӧ шувела, кар кодь пе лолэ да мыйке, ставыс пе сотчас. Ог тӧд ме. Мед эське Енмыс видзас же! Потолу что пе сія местасис, вӧр кор вӧлэла, став пуыс ӧти лунӧ пӧрлӧма. Ог тӧд тэсся. Тювӧд сідзи шулэма. Кар кодь пӧ лове. Ӧні эськӧ ёна строитчӧні сэні, сикт помас ёна стрӧитчӧні. Татчӧ вот некод оз стрӧитчи - лёк керка местаясыљ. Ся местаясыљ абу». этого вообще нет крыс?) Ни одной. Вот раньше на баржах привозили всё, и в Нившеру продукты для сельпо, и отруби для колхоза, всё на баржах привозили. Как только, мол, на Вишеру свернёшь, все [крысы] выпрыгивают, ни одной не остаётся. Ни разу не приходили [крысы]. Вот сколько барж прибывало, и чтоб здесь когда-то одна [крыса] была - ни одной нет. Он таким знающим был! [...]

Вот это слышала. У нас была одна - Ӧгрӧ Иван Долна ${ }^{12}$ звали. И она извозничала - до Нившеры подвозила кого-то и с Нившеры привозила. Мой муж как-то с ней ехал с Нившеры, и она рассказала: Тювэ сказал, мол, что деревня Троицк будет как город. Шутели ${ }^{13}$, говорил, будет как город, но полностью сгорит. Не знаю я. Пусть Бог хранит! Потому что на том месте, мол, когда ещё лес стоял, все деревья в один день были вырублены. Не знаю потом. Тювэ так говорил. Как город, мол, будет. Так-то теперь интенсивно строятся там, в конце деревни много строятся. Вот здесь никто не строится - для дома неподходящие места. Потом мест и нет.

Зап. А. Н. Рассыхаев 11.06.2012 в дер. Троицк Богородского с/с от Габовой Анны Александровны, 1931 г. р. 


\section{2.}

(Тюве йылысь кывлід?)

А.Д.: Ме ог ёнасэ куж.

A.С.: Подорова мед висьталас,

Тювеыд кыті потилэла да мьıйда майда.

B.А: Тювеыд сія крысаяссьыд потшлэла. Кыт вӧлэл баржаэн кае, сэсся сыльись пажунтэ ставсэ крысаяс сёясны мешексьыл. Сэсся Гӧрд бужед доре воас, да шуас, сэсся всё пе.

Г.Д.: Ростагъя.

B.A.: Али Ростагъя. Но Гӧрд бужедэн шуэны сіе.

Г.Д: Джияна коластас.

B.A.: Bот сэтче вовас дай шувас, всё пе, тіянль пе татчедз туйид и ем, сэсся водзе пе онэ льсьтэ кайны.

Г.Д: Но сія Ростагъя.

B.A.: Сэсся став крысаыс сэтче пьр пе четчалэны. Баржаясыљ пе кутасны кайны, да сія местаас воасны, да ставныс пе четчалэны. Г.Д: Ростагъя, кор Шойнатылас вӧлі ветлэнь, Джияна III о й н $a$ m bl $a \quad \kappa o c m a c$ Ростагйас сія, Джиянэдзыс Ростагъясяньис матынджык. Вӧлӧк коластыс, вуджны колэ сіе Джиянсянььс Шойнатыэдзыс сія коластас кӧнке. Ме тӧда сія Ростагъясэ, сія Джиянсянььс матынджык Ростагъяыс, чел Сторожевскедзыс, матынджык сія Ростагъяыс Джиянэдзыс сія матын, абу ёна ыльн. Ме эд сэті веттэдльвліл сія вӧовснад и быдсэн, бензинбясьдла Шойнатылад лэччьвлан да. (Тювеьс сія лиорт вӧлэма?)
(О Тювэ слышали?)

А.Д.: Я не очень хорошо знаю.

А.С.: Пусть Подорова рассказывает, где Тювэ перегородил и всякое такое.

В.А.: Тюве от крыс перегородил. Где на барже поднимался, весь его обед из вещмешка крысы съели. Потом доехал он до Красного обрыва и сказал, всё, мол.

Г.Д.: До Ростагъя.

В.А.: Или до Ростагъя, но называют это место Красный обрыв.

Г.Д.: Не доходя до Ивановской. B.A.: До туда доедет и скажет, всё, мол, вам путь только до этого места, дальше не смеете подниматься.

Г.Д.: Но это и есть Ростагъя.

B.А.: Все крысы там спрыгивают. Баржи поднимаются, до того места доходят, и все [крысы] выпрыгивают.

Г.Д: Ростагъя, это когда в Сторожевск ходили пешком, Ростагъя находится между Ивановской и Сторожевском, до Ивановской от Ростагъя ближе. Где-то на волоке между Ивановской и Сторожевском. Я знаю это место Ростагъя, Ростагъя ближе к Ивановской, чем к Сторожевску, Ростагъя ближе к Ивановской, недалеко. Мы там ходили и на лошадях ездили, когда за бензином в Сторожевск ходили.

(Тювэ - это человек был?)

В.А.: Человек. Тювэ говорил, что Троицк городом станет.

A.С.: А много и настроили, так ведь? Да. 
В.А.: Морт. Шульлллэма Tипе сиктын пе кар ловас, Тювеыд тоже шульллэма.

A.C.: А ёна на строитчисньи, да вед? Да. (Тіянль тае код висьтавліс?)

В.А.: Важzя йӧзыд тай висьтавльвлісньь.

Г.Д.: Тае вед корке газетӧ гижлісны и быдсэн, кыдзи локтэла - и быдсэн гижела вӧлі "Коми муэ", но менал паметей абу, да вуні же нин.

А.С.: Но кар пе ловас, а мыийке лёктор висьталэла же, ме ог тӧд, мый висьталэла. Шутел йывсьыс мыийке висьталэны, ог тӧд мыıй.

Г.Д.: Ӧні Шутемас, сія выльсладорас и сэтэн ольссьыс, татӧні вӧлӧсьтыс ставыс нин кулі. Шутемас сіл выльысь нин стрӧитчелась.

B.А.: Тӧдысь пе тай вӧлэла Тювеыс сія вот, тӧдысь пе вӧлэма. (А кӧн сія овлэла, Висерын?)

Хорол: Абу.

В.А.: Сія кӧнке увланьын вӧлэма, абу Висерын.

Г.Д.: Тюветэсіеёна нин гижлісны.
(Кто это вам рассказывал?)

В.А.: Старые люди рассказывали. Г.Д: Про это писали в газете, как он пришёл и обо всём было написано в газете «Коми му», но у меня память плохая, и всё уже забыла. A.С.: Ну, мол, город будет, и чтото плохое ещё предсказывал, я не знаю, что предсказывал. Про Шутем что-то рассказывали, не знаю что.

Г.Д: Сейчас в Шутеме, и на верхнем конце и в центре деревни все жители уже умерли. В Шутеме заново уж застролись.

В.А.: Говорят, знающим был Тювэ, знающий, мол, был.

(А где он жил, в Богородске?)

Хором: Нет.

В.А.: Он жил где-то в низовьях, не в Богородске.

Г.Д: О нём много писали.

Зап. Л. С. Лобанова 10.06.2012 в дер. Троицк (Типӧсикт) Богородского с/с от Габовой Анны Дмитриевны, 1938 г. р., Габовой Галины Дмитриевны, 1933 г. р., Подоровой Валентины Александровныа, 1950 г. р., Шучалиной Анны Степановны, 1951 г. р. 


\section{3.}

(Гашкӧ, кывлінныд Тюве йыьвсьысс) Да, вот ӧні дум вылло уси. Важ карта Лунь дорад выйим Висерад мунігӧн. Важ карта бужӧдад пӧ чеччыштас сэтчи, суныштас да вот этійӧ Пӧлян кӧтшасад юрсӧ мыччас.
(Может слышали что-то про Тювэ?) Да, вот сейчас вспомнила. Старый скотный двор есть около деревни $Л y н b^{14}$, по пути в Богородск. У этого старого скотного двора с обрыва, мол, прыгнет, нырнет [в реку Вишера], и здесь в [местечке] Пӧлян кӧтшас ${ }^{15}$ голову высунет.

Зап. А. Н. Рассыхаев 11.06.2012 в дер. Сюзяыб Богородского с/с от Мишариной Нины Александровны, 1929 г. р.

\section{4.}

A вот Тювӧтӧ вӧлі шувӧні. Сэтшӥм вреля пӧ ловӧ татӧн, аддзасні пӧ гач выьв пӧдпушкасӧ бабаясід, ок пӧ, (ой, юрӧй менам кьнлыллӧ татшём сёрнисьыс) коркӧ пӧ овлӧма тані мужик рӧд. Пондасні пӧ шуні бӧрбяпом. [...] Сэтшӧм вреля пё ловӧ. И победитасні пӧ Войвыььсянь, биттекӧ олӧмсӧ. Мыйкӧ война: войвыььсянь кутшӧлкӧ уськӧдчасні да победитасні пӧ.
А про Тювэ рассказывали. Такое время здесь, мол, настанет, увидят бабы подпояски штанов и заохают (ой, голова моя от этих разговоров «зябнет»), мол, когда-то здесь мужики жили. Будут, мол, под конец говорить. [...] Такое время, мол, наступит. И победят, мол, с Севера, как будто бы эту жизнь. Война какая-то - с севера нападут и победят [нас].

Зап. А. Н. Рассыхаев 11.06.2012 в дер. Сюзяыб Богородского с/с от Мишариной Нины Александровны, 1929 г. р. 


\section{5.}

То тай битэ, Висерад станииятэ вӧчисні. Кьљ ю костэ пе, Тювӧ шувӧ - зээ пӧ дьр оз ов станцияд. Вӧчлісні - быри. Битэ тай сетӧні вӧлі, электротӧ, ӧні кар сетӧ битӧ. Татчи пӧ эськӧ кык ю костас и би мыйкекерӧні, а оз дьр ов. Ӧні вот тай битӧ ог и сэтыссь ӧзтӧй - кар ӧзтӧ [...].

Гашкӧ и, стрӧитчигад Тювӧльсь жӧ и вӧлӧм ювалӧні тай. Керка лестатӧ сійӧ и вӧлӧл бӧрйӧ войдӧр. Вӧлі вӧд тай радӧн-радӧн стрӧитчӧні, а сэки тай керка местатӧ Тювӧдльсь и ювалӧні вӧлӧл стрӧитчигад. Сія пе и индас.
Вот электричество, в Богородске станцию сделали между двумя речками, Тювэ говорил - долго не проработает, мол, электростанция. Сделали - пришёл конец. Электроэнергию давали, а теперь - из города свет идёт. Здесь, мол, между двумя речками электростанцию [построят], но недолго просуществует. Теперь вот свет не оттуда берём - город зажигает. [...]

Возможно, перед строительством [дома] у Тювэ и спрашивали. Место для дома он и выбирал прежде. Ряд в ряд ведь строились, а тогда место под строительство дома у Тювэ и спрашивали. Он, мол, и показывал.

Зап. А. Н. Рассыхаев 11.06.2012 в дер. Сюзяыб Богородского с/с от Игушевой Розы Ефимовны, 1935 г. р., уроженки дер. Зулоб Большелугского с/с.

\section{6.}

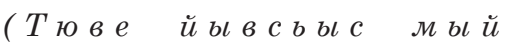
висьтавліснь?) Тювеыд тӧдса личность вӧлэма татэн. Сія олэла Пукдылмад, да сыльсь керка местаяссэ да мыйда ме на ачьлм аддзылльлі сіе 69-70-ой годбясын турун пуктіген. Сіе местаясыс Тюве керес, Тюве коськ вот, Тюве керка местас да кӧбрег местаясыс тӧдчены на вӧлі, керкаыслэн вӧліны селсятой годнад. (Ыльн тасянь?) Кьзь килолетра, навернэ, льддень вӧлі Висер кузяс. Да сія збыль
(Про Тювэ что рассказывали?) Тювэ был известной личностью здесь. Он жил в Пукдыме, место его дома и других [построек] я сама ещё видела в 69-70-ом годах во время сенокоса. Это место Тювэ-возвышенность, Тювэ-порог, место дома Тювэ, место погребка были ещё заметны в 70-ом году. (Далеко отсюда?) 20 км считали по реке Вишере. Да, это был реальный человек, всё это раньше помнили, мне тоже уже пожилые рассказывали, они..., придёт, мол, 
морт вӧлэла, сіе ставсэ вӧлэл корке помнитэны, меным пӧрысьяс же нин висьталісны, налс эсіе..., волас пе да шуве. Воас пе кад, ӧтик нянь шомесьсь пе нянь пондасны йӧзыд сёйны. Мун пе сӧрем пе сія. А сідзи и выйылм, ӧні ӧтик нянь шомесысь нянь сёял. Эся, но кад пе вовас, Висер ю пе кӧрт вӧнен вӧнясяс сія поскыд, вот сія. А ӧнія электростаниияыс кытӧн сулалэ, сэтэн пе пабрика, завод пе лове, вот тай сэтэн, мыйке. Сиксэ пе ставсэ черань везъен, черань вез сикт пасьталас нюжалас. (Аслас сельяэн олэма?) Ме ог тӧд, висьталэл сертиьлс челядыьс сэтэн абу нин вӧлэмась. (Гӧтырыс вӧлэма?) Нинэл, висьталэл сертиыс, дерт, колоке кодке вӧлі-я, наперво овлес вӧлэла сэтэн Тювеыслэн збыльысь, аслам синмен на аддзылі керка местаяссэ, кӧбрег гуясыс на тӧдчены. [...] и говорит [Тювэ]. Наступит, мол, такое время, из одной квашни все люди будут хлеб есть. Уйди, мол, это брехня. А так и есть на самом деле, сейчас с одной квашни хлеб едим. Потом, мол, настанет, время, река Вишера опоясается железным поясом это железный мост. А где сейчас электростанция находится, там, мол, фрабрика, завод будет, вот так и есть. Село всё окутает паутиной, паутина повиснет по всему селу. (У него семья была?) Я не знаю, по рассказам, детей у них там не было. (Жена была?) Никого, по рассказам..., может и был кто-то, но хозяйство у Тювэ там было на самом деле, своими глазами видела останки дома, были заметны ямы от погреба.

Зап. Л.С. Лобанова 09.06.2012 в с. Богородск от Каллистратовой Тамары Ефимовны, 1932 г. р.

\section{7.}

(Тюве йыльссь кывлід энэй?) Тювесэ миян маме покойнича, висьтавлэ же вӧлі, висьтоллэ. Сія вот тасянь кызь салс километра, сэн сія Пукдьмлас оллэма бураке. Тӧдллылэма мыйкеястэ. Сэк электричествоясыљ эз на вӧӧ, да сіе вот малей миян висьтоллэ вӧлі. Вӧлэл сія шуве Тювес, мьй
(Про Тювә слышали нет?) Про Тювә наша мама-покойница рассказывала. Вот отсюда больше чем за двадцать километров в Пукдыме он жил, кажется. Предсказывал это. Тогда электричества ещё не было, и мама моя рассказывала. Будто он, Тювэ, говорил, что в каждом доме 
быд керкан пе лове черань вез сія сутугаястэ вӧлэл мыйкекерэ. (Мый ешщи тӧдлэма?) Тювед сэсся мыйке, бытте олэм пе лове, сэтшел олэм, мый быд содка помын лове морт шуй сіе войнатэ тӧдлэла. А ӧні ме шула, сідз ке шуны, быд содка польєн и виены да зрыьитэны, да вед, алинь, алинь, бур йӧзсэ. (Корджьк сія овлэма?) Сіе вот ог тӧд. (Мамыљдяс дырйи?) Малеяс дырйи, сія тоже мелед, сія оз же вӧлэм тӧд Тювесэ, но йӧз сёрниысь, йӧз сёрни серти. Вот сія тоже морт вӧлэма. Мыйнэ тӧдысьясыљ эд унан эмесь, Большелугысь эд висьталэны же, кодэске, ог куж вот висьтовнысэ, кутшелке морт тоже тӧдысь вӧлэла, тунэн шувены вӧлі, тун. (Тӧдьсьссэ тунэн шувеньь?) Да. (Мый сія вӧчлэма?) Сія, навернэ, тоже олэл тӧдльллэла, водзе олэльястэ. будет паутина, это электрические провода так [называл]. (Что ещё предсказывал?) Тювэ [говорил], настанет, мол, такая жизнь, что на каждом крыльце будет труп это войну предсказывал. Сейчас я говорю, если так говорить, на каждом крыльце убивают и взрывают, и ведь аминь, аминь, хороших людей. (Когда это было?) Это вот я не знаю. (При жизни родителей?) При жизни родителей, мама тоже Тювэ лично не знала, но из разговоров людей, по разговорам людей. Он был реальный человек. Но так ведь знающих много, из Большелуга тоже рассказывали про кого-то, только вот назвать не могу, тоже был какой-то знающий человек, называли колдуном- $m y$ ном. (Знающего здесь называют колдуном тун?) Да. (Что он делал?) Он, наверно, тоже будущее предсказывал.

Зап. Л. С. Лобанова 11.06.2012 в с. Богородск от Габовой Тамары Николаевны, 1932 г. р.

\section{8.}

(Тюве йылысь мыйке кывлід?) Тюве йывсьыљ эське кыьллі, да мый сэсся ме, тӧдысь морт пе тай сія вӧлӧма. (Кӧні овлэла?) Пукдінын, участок Пукдылм, местность Пукдым гиж. (Кӧні сія Пукдылиьс?) Кьъз километра, тасянь кызь ӧтик Висер ю кузяс, по реке Вишере. (Сэн сылэн керка и быдтор эм?) Вӧлэма, гӧтыр
(Про Тювә что-то слышали?) Про Тювә что-то слышала, но что уж я, знающий человек, мол, был. (Где жил?) В Пукдыме, в местечке Пукдым, напиши Пукдым. (Где этот Пукдым?) В двацати километрах, отсюда по реке Вишере 21 км (Там у него дом и всё было?) Было, и жена была. (А дети?) Не было. (Сюда приходил?) Прихо- 
вӧлэла и. (А челядьыс?) Абу вӧльллэма. (Татче волььллэма?) Волльләма. Да сія и Тювед пе вӧлі висьталэ, этія кытӧні сеть электрољљ, татче пе керка стрӧитасны, ставыс пе вез, черань вез лове, вот сія водзвыьь и висьталлэма. А сэки нинэл на эз вӧӧ, провод ни нинэл, некӧн. Юысь пе чери быре, вӧрысь пе пӧтка быре, олӧм пе сэсся дженьыд нин лове. дил. И он, мол, Тювэ говорил, где эта электростация, здесь, мол, дом построят, и вокруг всё в паутине будет. Вот это он предсказывал. А тогда ещё ничего не было, ни проводов и ничего, нигде. В реке рыба пропадёт, в лесу дичь пропадёт, тогда уж жизнь короткой будет.

Зап. Л. С. Лобанова 11.06.2012 в с. Богородск от Ивашовой Лидии Васильевны, 1928 г. р., Мишариной Александры Васильевны, 1929 г. p.

\section{9.}

Тювӧ - сія важӧн кыськӧ локлӧм морт. Тювӧс-сійӧлоктӧм морт сія. Кьськӧ локлӧла да сэсся мунӧма Пугдылмӧ. Пугдылмыс кызз ӧти километра тасяньыьс. Сійӧ сэсся бьцдтор тӧдӧ вӧлӧм Тювӧс. Сія кутшӧлкӧ локтӧм морт, кутшӧлкӧ ссыльнӧй вӧлӧма. Сія вӧлӧм висьталӧ: мьıйкӧ пӧ, регьљ пӧ ловӧ мьıйкӧ, му вежандырйид. Шуалӧ пӧ, сиктылсад пӧ ставыс черань вез ловӧ - вот тая проволокалсыл, черань вез пӧ ставыс ловӧ. Эсся пӧ пондасні сэні мыйкекерні, сьыььні пӧ пондасні, кутшӧмкӧ пӧ абажур ловӧ да сьыььні пондасні. Вот сія Тювӧясыд важ, мыйкӧ тӧдсасӧ сія ставсӧ вӧлі висьталӧ. [...]

Эсся сія кууні пондас. Кууні пондас да гӧтырысль шувас, тэ пӧ мун. А гӧтырыс шувас, нелямин во
Тювэ - он откуда-то давно пришедший человек. Тювэ - он пришлый человек. Откуда-то пришёл и потом в Пугдылм ${ }^{16}$ ушёл. Пугдым - отсюда в двадцати одном километре. Тювэ всё знал. Он какой-то пришлый человек, какой-то сосланный был. Он рассказывал, что скоро будет светопреставление. Говорил, мол, в сёлах везде будет паутина - вот это провода, паутина, мол, везде будет. Потом, мол, там будут петь, какой-то абажур будет и будут петь. Вот они, такие как Тювэ, предсказывал раньше, что знал. $[\ldots]$

Потом он <Тювэ> стал умирать. Умирать стал и жене сказал, мол, ты уходи. А жена сказала, мол, сорок лет прожили [вместе], и не уйду же, не сбегу, говорит. Потом он, Тювэ, [умер], и как только 
пӧ олім, да ог жӧ пӧ мун, ог жӧ пӧ пышйь, шувалӧ. Сэсся сія, Тювӧд мыйкӧ, войшӧр кад лови да, Тювӧд пондас ветлӧдльні, корсьыссьні гӧтыртӧ. А ачыс сэсся кайӧ на паччӧрад, да тадзи гижтысьӧмӧн, висьталӧні, гижтысьӧма бабаыд да. Менӧ пӧ ся эз, ме пӧ сэсся гижтыси мыйкен, шолен. Ся ме дінӧ пӧ волас, этадз керасяс, оз пӧ менӧ аддзи. А эсся пӧ шувалӧ вӧлі мыцйке пон. Миян пӧ пон вӧлі сія да, понйыд ся уутні пондіс да ся бӧр зээ котӧра муніс, пырис, водіс пӧ ся бӧр. Бӧр пӧ водіс. Ся сія керка местас гувавлӧма вӧлі, ся ачыс и мунӧла вӧлі. Гӧтьюрыс мунӧма вӧлі сэтысь. А керкас сэсся мыйке, ог тӧд - сотіс ли колис, ог тӧд, мыий керис.

Тювӧс алинь сюсь морт вӧлӧма. Ссыльнӧй, кыськӧ вайлӧлась. Мыйкӧ тай шуласні, тайӧ пӧ Тювӧ керлӧма-я - миян татчӧ крысад оз лок. Татчӧ мыийӧн воас мыциккӧ дорӧдз, Шойнатьсянь петасні, Мусюрад, ӧти крыса пӧ оз коль, толькӧ пӧ ставыс лэбаласні. Тайӧ пӧ Тювӧ вӧчӧма, шуласні. Тювӧ пӧ керӧма. Сія Тювӧд ставсӧ вӧлӧм, морттӧ вӧлӧм оз жӧ тай, кулӧм морттӧ оз жӧ тай вӧлӧм лоозьӧд. Сь выйӧдз сюсь сійӧ вӧлӧма. [...]

Быљлат суналӧ. Ва улӧ суналӧ пӧ да оз пӧ и вӧй. Черитӧ пӧ кинас вӧлӧм куталӧ. Ог тӧд кутшӧм Тювӧс, мыийла сідзи, мый сэтшӧл. Кутшӧм сюсь морт, кутшӧм мый морт вӧлӧма сіе?

A Тювӧд кӧ пӧ мыйкӧ керас, вӧрасигъясььд, шувӧні, дашкӧ пӧ, он лыссьт вензььні - ся пӧ нинӧм, полночь настала, Тювэ стал ходить, искать жену. Поднимается на печь, а жена очертилась, рассказывают так, поднялась на лежанку печи и очертила вокруг себя [линию]. Меня, мол, потом не [нашёл Тювэ], я, мол, очертила вокруг себя угольком. Потом ко мне подойдёт, мол, вот так сделает <руками обыщет>, и не находит меня. А потом, говорит, собака была. У нас собака была, мол, собака начала лаять, и [Тювэ] быстро убежал, залез, лёг обратно [в гроб]. Обратно, мол, лёг [в гроб]. Потом она его на месте дома похоронила, а сама ушла. Жена ушла оттуда. А дом потом, не знаю - сожгла или оставила, не знаю, что сделала.

Тювэ был очень умным человеком. Ссыльный, откуда-то привезли его. Что-то говорили, мол, это Тювэ сделал - у нас здесь крыс нет. Как только дойдут к Мусюр, выехав со Сторожевска, ни одна крыса, мол, не остаётся, все выпрыгивают. Это, мол, Тювэ сделал, говорят, Тювә, мол, наколдовал. Тювэ всё мог, человека только, умершего человека только не воскрешал. Настолько смышлёным он был. [...]

Везде ныряет. В воду ныряет и не тонет. Рыбу, мол, руками ловил. Не знаю, какой Тювэ, почему так. Такой смышлёный человек, что за человек он был?

А если Тювэ, мол, наколдует во время охоты, говорили, не смеешь спорить с ним - потом ничего, ни одной дичи не поймаешь. Пусть только Тювэ к тебе придёт! Какойто такой знающий человек был. 
ӧти пӧтка оз шед. Толькӧ пӧ мед

Тювӧ волас тэ дінӧ! Кутшӧмкӧ

сэтшӧм тӧдысь морт вӧлӧма.

Зап. А. Н. Рассыхаев 12.06.2012 в с. Богородск от Габовой Августы Семёновны, 1935 г. p.

20.

Тювӧд коркӧ волӧма Висерӧдзыс, ся прӧйдитӧма да, Висерьн пӧ куим шудтӧм керка выйим, Тювӧ пӧ шувӧ. А кодъясльсь индоллӧма, мыйкӧ тай эстысь вӧлі вадорсььсс, ся сійӧ керкасӧ косялісныь. [...]

А сія шулӧма пӧ, Тювӧд, ӧні пӧ воас кад, да Висерӧ пе кар стрӧитасні. И гӧгӧр пӧ черань вез лове. Тювӧд шулӧма тае. Bот таес ставыс тӧдӧні. Кар пӧ стрӧитасні, шӧр туй вылӧ петасні. Сідз и лови! И ставыс пӧ черань вез лове. Станииятӧ миян стрӧитісні. А проводьц сочерань везыљ быттьӧ лыддьысьӧ. Тае пӧ черань везйьљ.

А сэсся пӧ ловӧ олӧм: поскапом на поскапол пӧ кутасні тышкасьні. Да мамыљ гу вылӧ пӧ мунан да бӧрддзан: мамӧ пӧ чеччы, ме тә места муна. А сія мый обозначайтӧ, некод оз тӧд. Ставыс шокын ся сія. Коді шуве, война лове, ставсӧ вияласні, ставсэ нувасні. Ся дӧваяс колям, пес вӧчись некод абу.
Тювә как-то приходил в Богородск, прошёлся и сказал Тювә, что в Богородске три несчастливых дома есть. А на чьи [дома] указывал, на какой-то там, у реки - потом этот дом разобрали. [...] А он, Тювә, говорил, что скоро настанет такое время, и в Богородске город построят. И вокруг, мол, паутиной покроется. Тювэ говорил это. Вот это все знают. Город построят, на основную трассу выйдут. Так и стало! И кругом паутина будет. Станцию у нас построили. А провода вот - это будто паутина считается, это, мол, паутина.

А потом, мол, жизнь наступит: крыльцо на крыльцо будут драться. На могилу матери, мол, пойдёшь и заплачешь: мама, мол, вставай, я вместо тебя лягу. А что это обозначает, никто не знает. Bce в шоке. Кто-то говорит, что война будет, всех поубивают, всех [мужчин] увезут. Одни вдовы останемся, никому будет дрова заготовливать.

Зап. А. Н. Рассыхаев 12.06.2012 в с. Богородск от Игушевой Лидии Ивановны, 1932 г. р. 


\section{1.}

(Тюве пе тай тані овлэма?) Тюветэ тані сёрнитэны вӧлі, сёрнитэны вӧлі. Ме нин татче локті, да Одыбын овлэма сіл, одьбсаьцд сіе висьталасньь. Татче пе юас суныштас, да кытчике Шойнатыэ петэ, ю пырыс кытке пе мунас, да ме сіе ог нин тӧд, сіе одыбсаьд, навернӧ, тӧдасны бурджыка. Татче корке волэма Тювеыс, пӧрысьяс мен висьталэны, вӧлӧсьтсэ кытшовтэла да висьталэла, кодьяслэн кутшел керкаыс. Вот менал керкай эстэні сулалэ, да сіе шувема шудтэмен, менсим керкасэ шувела шудтэлен. Сэсся мыйкеяс, Ольвылас сэні мӧд керка выйылм Микулай, кутшел Микулай сія и эл, сылысь тоже шувела шудтэм пе, Яшка Микулай. (Збыльысь шудтэл али абу?) А код тӧдэ, гозъя тай куліны томен-а, толен куліны, менам то семьяэй быри же, код тӧдэ. Сэсся сіе думайта же, колоке збыль. Сэсся коймед керка ешщи висьталэнь, сіе ог тӧд, кутшем керка, ог куж висьтавны. Сӧвет каднад эськи оз вӧлі веруйтны сэтшелгястэ.
(Говорят, Тювэ здесь жил?) Про Тювэ здесь говорили. Когда я сюда приехала, мол, он жил в Нившеpe, про это нившерские расскажут. Здесь, мол, нырнёт в реку и где-то в Сторожевске выныривает, под водой проходит, про это я уже не знаю, про это нившерские лучше знают. Сюда, мол, как-то приходил Тювэ, пожилые мне рассказывали, обошёл село и рассказал, у кого какой дом. Вот мой дом там стоит, и его назвал несчастливым, мой дом назвал несчастливым. Потом в местечке Ольвыь, там дом Миколы есть, как уж его по прозвищу, его дом тоже назвал несчастливым, у Яшки Миколы. (На самом деле несчастливый иль нет?) А кто его знает, супруги оба молодыми умерли, у меня семьи тоже не стало, кто знает. Потом думаю, что может и вправду. Ещё на третий дом указал, но его не знаю, какой дом, не могу сказать. При советской власти в такое не верили.

Зап. Л. С. Лобанова, А. Н. Рассыхаев 09.06.2012 в с. Богородск от Игушевой Веры Лукичны, 1923 г. р., уроженки дер. Лыаты Кожмудорского с/с Усть-Вымского р-на. 
Газетӧ нин вӧлі гижӧмась - Тювё ветлӧма Ленинльсь нянь корны. Сэтчӧ нин пысалӧлась, Тювӧсӧ нин гижӧмась. Кутшӧмкӧ вӧлӧм Епим - Ленинлысь няньсӧ корнь ветльиллӧма! (Л: Татчӧс, Висерса жӧ вӧлӧма?) Кьıськӧ Висерсььıс жӧ вӧлӧма. Грабитчӧ вӧлӧл, мьıйкекерӧ, грабиталӧ да мыйда шайкаясӧн, мыйкеясӧн вӧлі олӧ. Ся оз радейтні, висервожсатӧ весиг узьні оз вӧлӧм лэдзні. Оз весиг лысьтні висьтавні висервожсьыл, весиг узьнід оз лэдзні. Сэні, кар горувъясад, война кадъясад и начкасні, лэдзасні кӧ узьні. Вообше висервожсасӧ ненавидитӧні вӧлӧм. [...]

Сія шульлллӧма былттьӧ мыйкӧ, кор пӧОдыбволӧн чераньвезъялас, сэк пӧ война заводитчас. Война кор заводитчис, телепон таті мыйке Льмлваӧ нюжӧдлісньь. [...] А сія <шулӧма>: ме пӧ толькӧ кыкысь петалылла мыйкеӧ, берегас кайльлла. Висер волй, этатчӧ вӧлӧл Висерӧ суныштас, Розтагъя пе сир ьцжид, ньыльцштӧмыссь пӧ пола да петала. Да мӧдлат кыськӧ, налим пӧ, плӧш налил, да муннь ог пӧ верми. [...]

Вӧлӧма тӧдісь жӧ - Марья-мам, Ыджыдвиддзысь. Но пӧ ог тӧд нилсӧ, кутшӥл, мыьй и нилььс вӧлӧма, Соболь ли мыйли. Талун пӧ Марья-мам куусяс, локтас пӧ менӧ сёйні. Тә пӧ эн лэдз поскӧдыс вуджні, мед пӧ ю йыıытіс кытшоотас. А ю йыьытіс пока кытшоотас, шонді мыччысяс, ся пе менӧ сёйні оз верми. [...]
В газете писали, что Тювэ ходил хлеб просить у Ленина. К нему уже прицепили, о Тювэ написали. Какой-то Епим был, он ходил у Ленина хлеб просить! (Л: Он местный, из Богородска?) Откудато из Богородска был. Грабил он, грабительством занимался в шайке, этим жил. Потом не любят жителей бассейна Вишеры, даже на ночлег не пускали. Даже не смели представляться вишерскими, даже спать не пускали [в дома]. Там, ниже города <в низовьях Вычегды>, в годы войны и зарежут, если впустят спать. Вообще, вишерских ненавидели. [...]

Он как будто сказывал, мол, когда Нившеру паутина окутает, тогда война начнётся. Когда [Великая Отечественная] война началась, телефон отсюда до Лымвы ${ }^{17}$ протянули.

А он <Тювэ> говорил, что только дважды выходит <из воды>, на берег поднимается. В устье Вишеры, вот здесь в Вишеру нырял, в [местечке] Розтагъя ${ }^{18}$, мол, щука большая, боюсь, мол, что проглотит меня, поэтому выхожу [на берег]. И в другом месте [выходил на берег], мол, сплошь налим, и не может проплыть там. [...] Была тоже знающая - Марьямама, из Большелуга. Не знаю клички собаки, как звали собаку, Соболь или как. Сегодня, мол, Марья-мама умрёт, придёт меня есть. Ты, мол, не пускай её через мост, пусть, мол, обойдёт через верховье реки. А пока обойдёт через верховье реки, солнце взой- 
Татчӧ катӧ баржа, Висер воле мыен вови, сэсся ставыс [крысаыс] чеччалӧ. Cuпертас былме. Сипертас вӧсна пе сія оз верми пьюрні татчӧ. [...] (Р: А эз шулыны, мыцй Тювӧьсс крысаяссӧ накажитӧма, мыждӧма?) А кыцзкӧ кыьллі, сукар мешӧк пӧ сёйӧма. Сэтысь пе накажитӧма. [...]

A вот малӧ, поконича, вӧлі висьтоллас. Тая олӧм бӧрти пе, значит, зээ бур олӧм ловӧ, но регид кеже. Сэсся пӧ сы бӧрын олӧм ловӧ, да пондам джуджыдінын пӧдтьссьні да корсьні, да оз сюр. Рад лован кулӧмыс вылӧ пӧ, да он понды кууні. дёт, потом, мол, меня съесть не сможет. [...]

Когда поднимаются сюда баржи, заворачивают на р. Вишеру и все [крысы] выпрыгивают. [Здесь] марьин корень растёт, из-за марьиного корня они не могут подниматься сюда [...]. (Р.: А не говорили, что это Тювэ наказал крыс?) Слышал, говорили как-то, что крысы съели у него мешок сухарей, и за это он наказал их <крыс>. [...]

А вот мама моя, покойница, рассказывала. После этой жизни, мол, очень хорошая жизнь установится, но ненадолго. Потом после неё такая жизнь наступит, что будем в глубоком месте [реки] топиться, будем искать - но не найдём. Рад будешь смерти, но не сможешь умереть.

Зап. Л. С. Лобанова, А. Н. Рассыхаев 05.06.2013 в с. Нившера от Попова Петра Григорьевича, 1928 г. р., уроженца дер. Лымва.

\section{3.}

Висерӧ вотӧдз пӧ кытчӧкӧ петаллӧ, ьджыд сир пӧ тасасьӧма ю воменіс. Тая абу ьљжыд сир ю пасьта абу жё! Кутшӧлкӧ звер жӧ сэтчӧ пырӧма жӧ. Тювӧ пӧ тай вӧллӧма-я. [...] (Р: А сійӧ ва увті ветлӧдлӧма?) Тат пӧ суныштас, Одыбӧд суныштас да Висерӧ вотӧдз кьтчӥкӧ петалас. Ся бӧр пӧ суныцттас. Кььтчӧ мунӧ, ог тӧд. А ва пийӧ суныцштӧмӧн кӧ верлан
До Богородска где-то выходит [из реки Вишеры], потому что большая щука реку перегораживает. Не бывает же такой большой щуки размером с ширину реки! Зверь какой-то, наверно, там сидит. Тювә, говорят, был. [...] (Р: А он под водой ходил?) Вот здесь, мол, нырнёт, в Нившере нырнёт и где-то [не доходя] до Богородска вынырнет. Потом, мол, обратно нырнёт. Куда идёт, не знаю. А если может передви- 
мунньь, сія абу морт рӧд. Сія ог тӧд, мый рӧд сія. гаться, нырнув в воду, он не человеческого рода. Не знаю, какого рода он.

Зап. А. Н. Рассыхаев 06.06.2013 в с. Нившера от Абдулганиевой (в девичестве Жижева) Лидии Петровны, 1932 г. р.

\section{4.}

Сія шульллӧма, вот тані вед эз вӧӧлі некутшӧм этатшӧм проводгясыљ вообше, важентӧ, сія шульллӧма, сія тӧдысь морт вӧллӧма, шулӧма, тан пе дзоньнас пе черань вез лове. Сія сутуга черань везӧн шувені. Сія водзвыьы висьтольлэла. Кӧрт лэбачьяс пӧ кутасны лэбавні-сія салолёттӧ шулӧма.
Он <Тювэ> говорил, здесь ведь вообще не было никаких таких проводов, раньше-то, он говорил, он был знающим человеком, говорил, что здесь кругом паутиной окутает. Эти провода паутиной называли. Он заранее предсказывал. Железные птицы, мол, будут летать - так про самолёты говорил.

Зап. А. Н. Рассыхаев 06.06.2013 в дер. Тист Нившерского с/с от Жижевой Валентины Фёдоровны, 1949 г. р.

\section{5.}

Тювӧс, гашкӧ, висьталлӧ вӧлӧм. Мыйке пе, кыдзкӧ вӧлӧм шуве, тайӧ мыйкетӧ - сутугаястӧ. Мыєен нӧ вӧлі шуве? Черань вез пӧ лове. Пасьтала пӧ черань вез лове, да сэтшӧм олӧм пӧ лове лӧсьыљ, но пе регид кежӧ. Кокчӧрьяд пӧ кутасні ӧзтыны сюмӥд гырдзымйн, да ваё пӧ оз кутні лэдзні уськӧдчині. Сэтшӧм на пӧ олӧм ловӧ.
Тювә, наверно, рассказывал. Както он говорил про эти провода. Как их и называл? Паутина, мол, будет. Всюду паутина будет, мол, и такая хорошая жизнь установится, но ненадолго. Будут, мол, обёрнутую вокруг голени бересту поджигать, и в воду зайти не пустят. Вот такая ещё жизнь наступит.

Зап. Л. С. Лобанова, А. Н. Рассыхаев 07.06.2013 в дер. Ивановка Нившерского с/с от Жижевой Марии Елизаровны, 1919 г. p. 
26.

Тювӧд сія важӧн вӧлӧма. Сія вӧрасьні, вӧрасе вӧлі мыйкеад, Мартестан - тані Висер ю бокас Мартестан посёлок вӧлі, лесничество. Сьлӧн сэтӧн вӧлі вӧр керкас. Сія ме уже йӧз мыиикесянь [кьыллі].

Тювӧс..., волӧмась охотникьяс, кык охотник, узьны сы дінӧ вӧзйысясны. Тювӧд шувас: Ыджьљвидзсьыд пӧ, ная Вылибса вӧлӧмась, Матрен пӧ кулі, Сюзь Матрен ли кыљзи шувас. Сія пӧ кулі талун, да сія пӧ локтас менӧ сёйні. Менал пӧ сія пӧдруга вӧлі. Эг пӧ вай, сэсся пӧ сія шувис меньлл: кула пӧ да тэнӧ сёйні вола. Войшӧр кадын пӧ локтас сёйні. Но оз верлы менӧ сёйні. Выль кӧті пӧ кӧмӧдісні да вилььљд пӧ, да сія поссӧ оз верли вуджні. Пока пӧ кыттиовтас мыйкесӧ, сәсся пӧ сыллӧн времлс коле. И действительнӧ, войшӧр кад бӧрын пӧ пон кутіс уутні. Bот пӧ тай локтіс. Сэсся пон пӧ кытшовтні кутіс. Ӧні пӧ ся водӧ да узвӧ. Ӧні пӧ сэсся татчӧ оз нин лок.
Тювә давно был. Он охотился в Мартестане - здесь, на берегу Вишеры, был посёлок Мартестан, лесничество. У него там была лесная избушка. Это я уже от людей [слышал].

Тювэ..., пришли охотники, два охотника, и ночевать к нему попросились. Тювэ сказал: что из Большелуга, а они сами выльыбские ${ }^{19}$ были, Матрена умерла, Сюзь Матрена ${ }^{20}$ или как уж сказал. Она, мол, умерла сегодня и придёт меня съесть. Она, мол, была моей подругой. Не взял её в жены, тогда она сказала мне: умру, мол, и приду тебя съесть. В полночь, мол, она придёт есть. Но не сможет меня съесть. Новые коты ${ }^{21}$, мол, ей обули, они скользкие, и она не сможет через мост перейти. Пока, мол, она обойдёт [реку], её время пройдёт. И действительно, в полночь, мол, собака залаяла. Вот, мол, она пришла. Потом, мол, собака, пошла обходить [реку, лая вслед за Матреной]. А теперь, мол, ложитесь и спите. Теперь, мол, сюда уже не придёт [Матрена].

Зап. Л. С. Лобанова, А. Н. Рассыхаев 07.06.2013 в дер. Ивановка Нившерского с/с от Иванова Семёна Елизаровича, 1929 г. р. 


\section{7.}

Шувӧла [Тювеььс] быттьӧнкӧсь, кор пӧ Нившераьı да Тистыс ӧтласяс, сэк пӧ олӧм поласяс. Ме вот сійӧ кывлі, мыий черань везбяс ловені - воздухас пӧ ловені черань везъяс. Сія имеитӧла виду мыйкетӧ, электричествотӧ. Ловені пӧ черань везъяс от деревни до деревни. Нившераыслӧн да Тистыслӧн вед вӧлі расстояние на, километра кылин, да стрӧитчисні, ӧні даже коластыс абу. Сэк пӧ олӧм помасяс.
Вроде бы [Тювэ] сказал, мол, когда Нившера и Тист соединятся, тогда и жизнь закончится. Я вот слышала, что паутина появится - в воздухе, мол, паутина появится. Он имел в виду әлектричество. Появится, мол, паутина, от деревни до деревни. Между Нившерой и Тистом ведь было ещё расстояние, примерно с километр, но застроили, сейчас даже промежутка нет. Вот тогда, мол, жизнь закончится.

Зап. Л. С. Лобанова, А. Н. Рассыхаев 08.06.2013 в дер. Алексеевка Нившерского с/с от Габовой Анны Николаевны, 1961 г. p.

\section{8.}

Тист юсӧ пӧ полласні керйӧн, ся регыд пё и [олӧм поласяс]. $<$ Тювеыд> абу тай тӧдлӧма прамӧя. Зэв нин важ, кор керсӧ юӧдіс ләдзӧні, немнас нин. Ӧні важён кертӧ оз ләдзні, ставсӧ машинан нувӧні. (Р: Сійӧ мый пӧ: Тист юсӧ полласны керйӧн, сэсся...?) Ся регыд пӧ и олӧм помасяс.

Сія пӧ вӧлӧм суныштас да ылӧдз мунӧ суныштӧмӧн. (Р: Тані суньцтӧ?) Да, татӧн пӧ суныцитас да Ягвыьь дорӧдз суньцтӧмӧн мунӧ вӧлӧм.
Речку Тист, мол, перегородят брёвнами, после этого вскоре [жизнь закончится]. [Тювэ] и не знал на самом деле. Давно уже, когда брёвна по реке сплавляли, давно уже [перегораживали]. А теперь уже брёвна не сплавляют, всё на машинах увозят. (Р: Что это значит: речку Тист перегородят брёвнами, потом ...?) А потом скоро, мол, и жизнь закончится. Он <Тювэ>, говорят, нырнёт было [в воду] и далеко под водой проходит. (Р: Здесь ныряет?) Да, здесь, мол, нырнёт и до [местечка] Боровска ${ }^{22}$ под водой проходит.

Зап. Л. С. Лобанова, А. Н. Рассыхаев 08.06.2013 в с. Нившера (мест. Тист) от Жижевой Александры Матвеевны, 1928 г. p. 
29.

Тювӧд шувӧма: Джиян поскӧдз пӧ крыса локтас, а сы бӧрын пӧ оз лок. Сэсянь пӧ сія чеччас баржа выьысыыд, чеччаласні. [...] Сія тай Тистӧ оолӧдчылэла-я. (Р: Тювӧьс?) Да. Сылісь керкасӧ ся тӧӧ-пурга нувӧма мыйке, Нюрдіӧдз, иувӧні вӧлі. [...] (Л: Ті шуинныц - Тист Иван. Сійӧ да Тювӧвıс - разнӧй йӧз?) А сія, навернӧ, ӧтик и ел.
Тювә сказал: до моста у Ивановской, мол, крысы дойдут, а дальше того места не пойдут. Начиная с того места, мол, [крысы] выпрыгивают с баржи. [...] Он в Тисте поселился (Р: Тювэ?) Да. Его дом потом сильным ветром унесло до Нюрд $i^{23}$, так место называли. [...] (Л: Вы сказали - Тист Иван. Он и Тювэ - разные люди?) А это, наверно, один и тот же [человек].

Зап. Л. С. Лобанова, А. Н. Рассыхаев 07.05.2014 в с. Нившера от Подоровой Марии Ивановны, 1932 г. р. 


\section{Примечания}

1 Иван из дер. Тист.

2 Тювӧ кӧдж (букв. излучина Тювэ) - урочище по р. Вишера выше с. Богородск.

3 Гӧрд чой (букв. Красная гора) - местечко на р.Вишера между Большелугом и Сторожевском.

4 В словарях сипертас переводится как 'заячий горох' [ССКЗД: 337], но индрманты указывают на растение марьин корень или пион уклоняющийся (лат. Paeónia anómala), про который поётся в известной песне «Маръямоль» (сл. Геннадия Юшкова, муз. Вацлава Мастеницы).

5 Мусюр 'водораздел', данным топонимом обозначается лесная полоса между бассейнами реки Вычегда и её притока Вишера по пути то Сторожевска в Большелуг.

6 Гӧрд чой 'Красная гора' - местечко на берегу р. Вишера.

7 Борганшор - ручей, делящий дер. Выльыб на части.

8 При повторной записи текста информант без сомнения называет персонаж - тӧдысь баба 'знающая женщина'.

9 Вариант этого текста был записан от этого же информанта через два дня Людмилой Лобановой. В целях экономии места текст не приводится. Основное отличие второго варианта заключается в том, что другая знающая приходит убить Тювә.

10 Другим человеком, о котором информант рассказал ранее, была Богоматерь, приплывшая на дырявой лодке.

${ }^{11}$ Шудог - приток Вишеры.

12 Домна - дочь Ивана, сына Аграфены.

${ }^{13}$ Шутем - название нижней части дер. Троицк

14 Лунь - деревня недалеко от Богородска.

${ }^{15}$ Пӧлян кӧтшас - излучина на Вишере между дер. Зулэб и Сюзяыб.

16 Пугдым - левый приток Вишеры, устье находится выше Богородска.

17 Лымва - деревня в 30 км от Нившеры в верховьях р. Лымва, впадающей в р. Нившера около с. Нившера. В 1970-ые гг. была признана «неперспективной», ныне пустует.

${ }^{18}$ Розтагъя - урочище на р. Вишера. 
${ }^{19}$ Выльыб - деревня в сельском поселении «Большелуг» Корткеросского района.

${ }^{20}$ Сюзь Матрен - букв. Матрёна по прозвищу Сова.

${ }^{21}$ Коты - вид кожаной обуви.

${ }^{22}$ Боровск (коми Ягвыы) - ныне часть с. Нившера, ранее - отдельная деревня.

${ }^{23}$ Нюрді - название места, букв. островок на болоте.

\section{Литература}

Анкудинова, Марина \& Филиппова, Валентина (сост.) 2005. Историческая память в устных преданиях коми: Материальь. Сыктывкар, 106-108.

Жаков, Каллистрат 1908. Зырянскія сказки. - Живая старина. Вып. I, 92-100; вып. II, 232-242. СПб.: Тип. МПС Тов. И. Н. Кушнеревъ и К.

Лимеров, Павел (сост., предисл., примеч. и пер.) 2005. Му пуксьӧл - Coтворение мира. Сыктывкар: Коми книжное издательство, 314-326, $587-588$.

Конаков, Николай 1999. Тювӧ. - Мибология коми. Энщиклопедия уральских мифологий. Т. 1. Москва-Сыктывкар, 364-365.

Панюков, Александр 2002. Григорий Коюшев, по прозвищу Тюве, значит, «быстрый». - Apm. № 4. 126-131.

Рочев, Юрий (сост.) 1984. Коли предания и легенды. Сыктывкар, 76-81.

Рочев, Юрий 1994. Тювӧ - Висер вожса предание (Тювэ - вишерское предание). - Войвыьв кодзув. № 7. 70-74. 


\section{ФОЛЬКЛОРИСТИКА КОМИ: исследования и материалы}

\section{http://www.folklore.ee/rl/pubte/ee/sator/sator17/}

ISSN 1736-0323

ISBN 978-9949-586-24-0

DOI: $10.7592 /$ Sator.2016.17

Тарту 2016

Авторы: Ирина Ильина, Юлия Крашенинникова, Павел Лимеров, Людмила Лобанова, Светлана Низовцева, Алексей Рассыхаев, Анатолий Панюков, Галина Савельева,

Олег Уляшев

Редактор серии: Маре Кыйва

Редакторы-составители выпуска: Людмила Лобанова \& Николай Кузнецов

Оформление обложки: Анатолий Панюков \& Андрес Куперьянов

Верстка \& HTML: Диана Кахре

Печатное издание: ФОЛЬКЛОРИСТИКА КОМИ: исследования и материалы. SATOR 17. Тарту 2016

Составление, техническое оформление и печать книги осуществлены при поддержке Эстонского институционального исследовательского гранта 22-5 (Религиозные и нарративные аспекты фольклора).

Оформление электронного издания осуществлено при поддержке проекта ЕККМ14-344 “Расширение областей применения и представление эстонского языка, культуры и фольклора в электронных информационных средствах".

(с) EKM Teaduskirjastus / Научное издательство ЭЛМ

(c) Авторы

(с) Анатолий Панюков \& Андрес Куперьянов 